\title{
Polymorphisms variants of the MTHFR C677T and PAI-1 5G/4G genes and their combinations in the group of children with arterial ischemic stroke
}

\section{Polimorficzne warianty genów MTHFR C667T oraz PAI-1 5G/4G oraz ich kombinacje w grupie dzieci $z$ udarem niedokrwiennym mózgu}

\author{
Nataliya Smulska* (D) Zoia Rossokha**(D), Liliya Fishchuk**(D) , Nataliya Gorovenko***(D), Alla Nechai* \\ (D), Iryna Nicolaenko* (D), Viktotiia Rysliaieva* (D), Iryna Krasilenko* (ID) \\ *Neurological Department, City Clinical Children's Hospital N ${ }^{0} 1$ in Kyiv, Ukraine \\ **Institution Reference-centre for Molecular Diagnostic of Public Health Ministry of Ukraine, Kyiv, Ukraine, ${ }^{* * *} 3$ The National \\ Medical Academy of Postgraduate Education State named after P.L. Shupyk, Kyiv, Ukraine \\ DOI:10.20966/chn.2020.58.455
}

\section{ABSTRACT}

Introduction. Arterial ischemic stroke (AIS) in childhood is a disorder associated with different predisposing factors, thrombophilia is one of them. We present the study of the MTHFR C677T and PAI-1 5G/4G gene polymorphisms as a possible risk factor for the development of AIS in the group of Ukrainian children.

Materials and methods. 77 children from 29 days to 15 years of age were involved in this study: study group - 44 children with AIS, and 33 in a control group. Children enrolled to both groups were at similar age.

Results. In the study group there was an increase in the frequency of genotypes 677CT (OR $=2.69)$ and 677TT, CT + TT genotypes (OR $=3.67)$ of the MTHFR gene, increased frequency of the $677 \mathrm{~T}$ allele $(\mathrm{OR}=2.57)$. In the study group detection of $5 G / 5 G+5 G / 4 G$ genotypes was higher $(O R=2.82)$ with statistically predominance of the $5 \mathrm{G}$ allele $(\mathrm{OR}=2.26)$ of the gene PAI -1. Higher frequency of the combination of genotypes genes $677 \mathrm{CT}+5 \mathrm{G} / 5 \mathrm{G}$ was found in the main group. The model of interpreting interactions was built, it allows to predict indirectly the potential intergenic interactions.

Conclusions. We conclude that risk of AIS is higher in children with polymorphic variants $677 \mathrm{CT}$ and $677 \mathrm{TT}$ for the MTHFR gene; the association of polymorphic variants $5 \mathrm{G} / 4 \mathrm{G}$ and $5 \mathrm{G} / 5 \mathrm{G}$ for the PAI-1 gene with a decrease in the risk of developing AIS; direct interaction with the MTHFR was found for PAI-1, but of weak strength.

Key words: schildren, arterial ischemic stroke, MTHFR C677T gene polymorphism, PAl-1 gene polymorphism.

\begin{abstract}
STRESZCZENIE
Wstęp: Udar niedokrwienny (AIS) jest rzadkim schorzeniem wieku dziecięcego, które wiąże się z różnymi czynnikami predysponującymi. Trombofilia jest jedną z ustalonych predyspozycji genetycznych do udaru w populacji pediatrycznej.

Cel: Przedstawiamy badanie polimorfizmów genów MHFR C677T i PAI-1 5G / 4G jako potencjalnego czynnika ryzyka rozwoju AIS indywidualnie i łącznie w grupie dzieci ukraińskich.

Materiat i metody Badaniem objęto 77 dzieci w wieku od 29 dni do 15 lat: grupa badana - 44 dzieci z AIS oraz grupa kontrolna - 33 dzieci zakwalifikowanych do obu grup znajdowały się w podobnym wieku.

Wyniki: W badanej grupie stwierdzono większą częstość genotypów 677CT $(\mathrm{OR}=2,69)$ i 677Tा, genotypów $\mathrm{CT}+\Pi \mathrm{T}(\mathrm{OR}=3,67)$ genu MTHFR oraz większą częstość allelu 677T (OR $=2,57)$. W analizowanej grupie wykrywalność genotypów 5G / 5G + 5G / 4G była wyższa $(\mathrm{OR}=2,82)$ przy statystycznej przewadze allelu $5 \mathrm{G}$ $(\mathrm{OR}=2,26)$ genu PAl -1 . Ponadto $\mathrm{w}$ analizowanej grupie pacjentów stwierdzono większą częstość kombinacji genotypów 677CT $+5 \mathrm{G} / 5 \mathrm{G}$ w porównaniu z grupą kontrolną.

Wnioski: Uzyskane wyniki badań pozwalają na stwierdzenie, że ryzyko wystąpienia AIS u dzieci jest wyższe w przypadku obecności polimorficznych wariantów 677CT i 677TT dla genu MTHFR; z kolei skojarzenie wariantów polimorficznych 5G / 4G i 5G / 5G dla genu PAI-1 wiąże się ze zmniejszonym ryzykiem rozwoju AIS. Stwierdzono także występowanie bezpośredniej interakcji MTHFR z PAI-1, jednak o małej sile oddziaływania.
\end{abstract}

Słowa kluczowe: dzieci, udar niedokrwienny tętnic, polimorfizm genów MTHFR C677T, polimorfizm genów PAl-1

\section{INTRODUCTION}

Arterial ischemic stroke (AIS) is a rare disorder of childhood with different risk factors and prognosis. Over 100 risk factors for stroke have been reported. There is a large number of publications studying in detail the risk factors for stroke in childhood [1-6]. Understanding the etiology and studying the cause of pediatric stroke are very important for management during the acute period, prevention of recurrent strokes and prediction of outcome for each child [7].

Thrombophilia is one of the established genetic predispositions for stroke [4-6].
Gerstl L. et al in their publication emphasize that children can have prothrombotic risk factor itself, an isolated versus/and combined occurrence non-prothrombotic [7]. Barnes Ch. et all have reported that prothrombotic abnormalities were identified in $20-50 \%$ of children presenting with AIS and in $33-99 \%$ of children with cerebral sinus venous thrombosis [8]. A large number of articles has been published on the influence of prothrombotic risk factors for the development of the IS in childhood. In their publication, Zadro R. et al in 2012 pointed out that the most important prothrombin risk factors for childhood strokes 
were FV Leiden, FII G20210A, MTHFR C677T, elevation in homocysteine and lipoprotein (a), PC (protein C) and PS (Protein S) deficiency, Plasminogen activator inhibitor-1 (PAI-1) 4G/5G polymorphism and Factor XIII [9]. There are several meta-analyzes and systematic reviews dedicated to these [10-14]. Some authors also emphasize that the Angiotnsin-1 Converting Enzyme (ACE) gene mutation affects the predisposition for stroke [15]. The importance of thrombophilia in AIS etiology has been emphasized in recent years, as the associations between polymorphisms of genes encoding proteins of the coagulation system and homocysteine metabolism were reported in numerous population studies [16]. This issue has been studied in pediatric stroke groups in Croatia, Poland and Germany, and we just wanted to test how it happens in children in Ukraine $[9,10,12,16]$.

Earlier, we reported the results of our study on the role of polymorphic variants of folate metabolism genes MTHFR C677T, MTHFR A1298C, MTRR A66G, coagulation factor genes - FV G1691A, FII G20210A, cardiovascular gene - ACE I/D, their combinations and intergenic interactions for the development of ischemic strokes in the group of Ukrainian children [17-19]. We found that the FV G1691A, FII G20210A did not have influence on the development of the strokes in the groups we analyzed. [17, 19].

As a result of the analysis of previously published data, it is possible to derive a schematic representation (Figure 1) of the results using the method of classification and regression trees (RapidMiner program) [http://rapid-i.com], which allowed us to create an algorithm for step-by-step analysis of the risk of developing a stroke in children with genetic component disorders. sis of ischemic stroke [20]. C677T polymorphism is associated with decrease in enzyme activity and ultimately leads to the increase of the concentrations of homocysteine [20], its high level leads to endothelial damage, impaired proliferation and coagulation of vascular smooth muscles which is the cause of the formation of blood clots. Most common MTHFR polymorphism is a cytosine (C) to thymine (T) substitution at position 677 , which leads to the conversion of alanine to valine at amino acid 222 of the enzyme. [21].

It is also known that the most significant role in the pathogenesis of ischemic stroke is played by changes in the hemostasis system, which leads to the formation of fibrin clots (thrombi and emboli) which, in turn, causes an acute violation of cerebral circulation. Simultaneously with the formation of clots, the fibrinolytic system is activated. One of the key regulators of the fibrinolysis system is the type 1 plasminogen activator inhibitor (PAI-1). It has been shown that the level of PAI-1 (SERPINE 1) in blood plasma is associated with polymorphism in the region of the promoter of the PAI-1 gene, which is a deletion/insertion of one nucleotide of guanine $(4 \mathrm{G} / 5 \mathrm{G})$ [22]. Genetic risk factors for thrombosis, depending on the number of identified associations - according to HUGE Navigator, can be divided into three groups: strong, moderate and weak [23]. PAI-1 is one of the leading (strong) genetic factors predisposing to ischemic stroke [24].

In the mentioned own study we did not analyze the presence of the mutation/polymorphism of the gene PAI-1 $5 \mathrm{G} / 4 \mathrm{G}$ in the children with AIS.

Having the data that the MTHFR C677T gene polymorphism is dominant among children with AIS in the gro-

Figure 1. "Genetic network" for forecasting the risk of AIS in children.

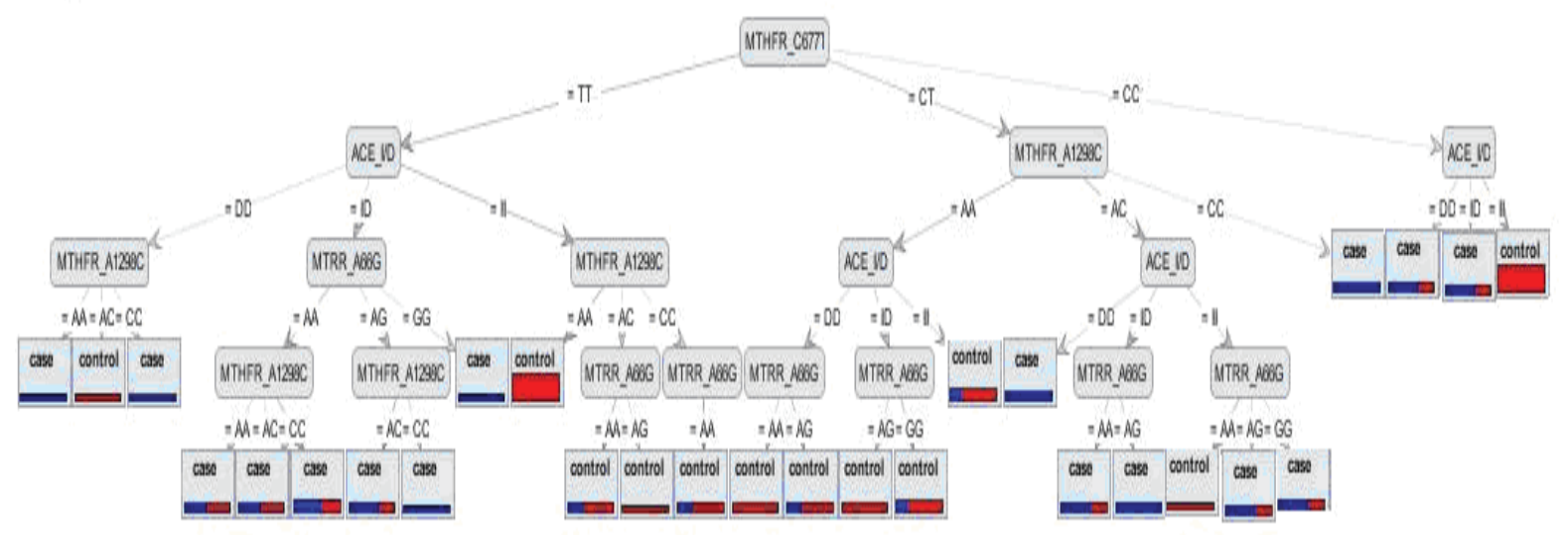

We showed that the risk of developing ischemic stroke in children was determined by the C677T polymorphism of the MTHFR gene. Due to this dominant significance we focused on the need for priority analysis of this genotype.

5,10-Methylenetetrahydrofolate reductase encoded by the MTHFR gene is a key control enzyme which is connected to the metabolism of homocysteine, which plays an important role in vascular function; and there is a growing evidence that homocysteine contributes to the pathogene- up of Ukrainian population, and knowing that the PAI-1 $5 \mathrm{G} / 4 \mathrm{G}$ gene polymorphism is one of the strong genetic factors predisposing to ischemic stroke according to literature data, we decided to study the hypothesis that the individual and combination of polymorphism of these genes can affects the occurrence of AIS in childhood. 


\section{PURPOSE}

The purpose of the present work is to study the MTHFR C677T and PAI-1 5G/4G gene polymorphisms as a possible risk factor for the development of AIS individually and in combination in the group of Ukrainian children.

\section{MATERIALS AND METHODS}

\section{STUDY POPULATION}

Our study involved 77 children from 29 days to 15 years of age, admitted to the Kyiv City Clinical Children's Hospital №1 from 01.01.2009 to 01.04.2020.

Study group included 44 children: 26 were boys $(59,1 \%), 18$ - girls $(40,9 \%)$; they were examined and treated in the Neurological Department. The including criteria for the main group were:

- age from 29 days to 15 years,

- acute phase of AIS,

- persistent neurological deficits for 24 hours or more. Exclusion criteria were:

- the age of patients younger 29 days and older than 15 years,

- neurological deficit due to other than acute AIS causes.

Confirmation and verification of the nature of patients symptoms were studied using neuroimaging methods MRI (magnetic resonance) and / or CT (computed tomography) of the brain. We studied the history of life (past history of the child's delivery, the condition of the newborn, developmental data in the sense of a milestone in psychomotor development, diseases in the child's past) and the first symptoms of an acute onset of the disease, performed neurological examination. Electroencephalography, electrocardiography, echocardiography were performed in all patients.

The control group included 33 children: 21 were boys $(63,6 \%), 12$ - girls ( $36,4 \%)$, aged from 29 days to 15 years. They were from the same region as patients with no history of neurologic or thromboembolic disease. Controls were hospitalized at the same hospital with mild respiratory diseases or for minor surgery.

The present study was performed in accordance with the ethical standards established in the updated version of the 1964 Declaration of Helsinki, and the ethics committee The National Medical Academy of Postgraduate Education State named after P.L. Shupyk approved the study. Written information consents were obtained from parents of all children included in the study.

\section{BLOOD SAMPLING AND DNA ANALYSIS}

The material for the examination was the peripheral blood, collected under sterile conditions in $1.2 \mathrm{ml}$ test tubes with EDTA (,Sarsterdt” Germany). Polymorphic variants of the MTHFR C677T and PAI-1 5G/4G genes were analyzed using PCR and RFLP with visualization in $2 \%$ agarose gel.

\section{STATISTICAL ANALYYIS}

The obtained results of the frequency of the presence of polymorphic variants of genes in children with AIS and of the control group were subject to statistical analysis (Statistica 6.0) with the definition of $\chi^{2}$ - Pearson's test using Yates' correction for continuity and odds ratio (OR) with a confidence interval $(\mathrm{Cl})$ of $95 \%$. Differences were considered statistically significant with the $\mathrm{P}$ value below 0.05 .

To study the possible interaction of polymorphic gene variants signaling pathways in protein, the interactions were analyzed using the STITCH database.

\section{RESULIS}

The analysis of data from medical records of 44 children from the study group showed that AIS is manifested as hemiplegia, balance disturbance, seizures or aphasia. The characteristic of children with AIS, including gender and age of acute stroke, is displayed in table I.

Numbers of boys were higher, both in the study and in the control group, which corresponds to the literature data [25]. The groups did not differ significantly in sex ratio $(p>0,05)$ (Table I). In our study, in the group of children of the first year of life and children aged from 1 to 6 years old, acute strokes were observed more often than in other age groups (34,1\% and $43,2 \%$, respectively). The median age at onset of acute stroke in the study group was 177.0 \pm 45.7 months.

Table I. Gender and age distribution of the studied population

\begin{tabular}{|l|l|l|c|}
\hline \multicolumn{2}{|c|}{} & \multicolumn{1}{|c|}{ Boys } & \multicolumn{1}{c|}{ Girls } \\
\hline \multirow{2}{|c|}{ Study group (n=44) } & $\mathbf{2 6}(59,1 \%)$ & $\mathbf{1 8}(40,9 \%)$ \\
\hline Age & $\begin{array}{l}29 \text { days }-11 \text { months } 29 \\
\text { days }\end{array}$ & $9(34,7 \%)$ & $6(33,3 \%)$ \\
\cline { 2 - 4 } & $\begin{array}{l}1 \text { year }-5 \text { years } 11 \\
\text { months 29 days }\end{array}$ & $11(42,3 \%)$ & $8(44,4 \%)$ \\
\hline & $\begin{array}{l}6 \text { years }-11 \text { years } 11 \\
\text { months 29 days }\end{array}$ & $3(11,5 \%)$ & $1(5,6 \%)$ \\
\hline & $\begin{array}{l}12 \text { years }-14 \text { years } 11 \\
\text { months29 days }\end{array}$ & $3(11,5 \%)$ & $3(16,7 \%)$ \\
\hline \multicolumn{3}{|c|}{ Median age $177.0 \pm 45.7$ months } \\
\hline Control group (n=33) & $21(63,6 \%)$ & $12(36,4 \%)$ \\
\hline
\end{tabular}

38 children (86.4\%) of the study group underwent CT of the brain in the first 24 hours after the onset of acute symptoms. According to CT data, there were no changes in 10 children $(26,3 \%)$. MRI was performed on 42 children $(95,5 \%)$ of the study group. The time of the MRI scan ranged from 5 hours after the onset of the first symptoms to 4 days. All children showed changes on MRI consistent with the diagnosis of AIS. MRI and CT scan were performed on 36 children $(81,8 \%)$ of the study group.

First of all, we studied the possible effect of polymorphic variants of the MTHFR C677T and PAI-15G /4G genes on the development of ischemic strokes in children. 
Table II. Distribution of genotype frequencies by the MTHFR C677T and PAII 5G/4G genes in the studied groups.

\begin{tabular}{|c|c|c|c|c|}
\hline \multicolumn{2}{|c|}{$\begin{array}{c}\text { Gene (Gene Variant) / } \\
\text { genotype }\end{array}$} & Study group $(n=44)$ & Control group $(n=33)$ & Significance of differences \\
\hline \multirow{6}{*}{$\begin{array}{l}\text { MTHFR } \\
\text { C677T }\end{array}$} & 677CC & $13(29,5 \%)$ & $20(60,6 \%)$ & $\begin{array}{l}x^{2}=7,43, p=0,006 \\
O R=0,27(0,11-0,71)\end{array}$ \\
\hline & 677CT & $28(63,6 \%)$ & $13(39,4 \%)$ & $\begin{array}{l}x^{2}=4,75, p=0,035 \\
O R=2,69(1,06-6,82)\end{array}$ \\
\hline & $677 \mathrm{TT}$ & $3(6,8 \%)$ & $0(0,0 \%)$ & $p>0,05$ \\
\hline & $\begin{array}{l}\text { 677CT+ } \\
\text { 677TT }\end{array}$ & $31(70,5 \%)$ & $13(39,4 \%)$ & $\begin{array}{l}x^{2}=7,43, p=0,006 \\
O R=3,67(1,42-9,51)\end{array}$ \\
\hline & $677 \mathrm{C}$ allele & 0,61 & 0,80 & $\begin{array}{l}x^{2}=7,43, p=0,006 \\
O R=0,39(0,19-0,82)\end{array}$ \\
\hline & 677T allele & 0,39 & 0,20 & $\begin{array}{l}x^{2}=7,43, p=0,006 \\
O R=2,57(1,22-5,40)\end{array}$ \\
\hline \multirow{6}{*}{$\begin{array}{l}\text { PAl-1 } \\
5 \mathrm{G} / 4 \mathrm{G}\end{array}$} & $5 G / 5 G$ & $9(20,5 \%)$ & $2(6,1 \%)$ & $p>0,05$ \\
\hline & $5 \mathrm{G} / 4 \mathrm{G}$ & $24(54,5 \%)$ & $15(45,5 \%)$ & $p>0,05$ \\
\hline & $4 G / 4 G$ & $11(25,0 \%)$ & $16(48,5 \%)$ & $\begin{array}{l}\mathrm{x}^{2}=4,57, \mathrm{p}=0,033 \\
\mathrm{OR}=0,35(1,21-17,92)\end{array}$ \\
\hline & $5 G / 5 G+5 G / 4 G$ & $33(75,0 \%)$ & $17(51,5 \%)$ & $\begin{array}{l}x^{2}=4,57, p=0,033 \\
O R=2,82(1,08-7,41)\end{array}$ \\
\hline & $5 \mathrm{G}$ allele & 0,48 & 0,29 & $\begin{array}{l}x^{2}=5,66, p=0,017 \\
O R=2,26(1,15-4,45)\end{array}$ \\
\hline & $4 \mathrm{G}$ allele & 0,52 & 0,71 & $\begin{array}{l}x^{2}=5,66, p=0,017 \\
O R=0,44 \quad(0,22-0,87)\end{array}$ \\
\hline
\end{tabular}

In the main group there was an increase in the frequency of genotypes $677 \mathrm{CT}(\mathrm{OR}=2.69)$ and 677TT and their greatest increase when the genotypes CT $+\mathrm{TT}(\mathrm{OR}=3.67)$ of the MTHFR gene were combined. The frequency of distribution of the $677 \mathrm{~T}$ allele was significantly increased in the group of children with AIS, in contrast to children in the control group $(\mathrm{OR}=2.57)$ (table II).

A comparative analysis of PAI-1 5G/4G gene polymorphism in the group of children with AIS revealed statistically significant prevalence of the $5 \mathrm{G}$ allele $(\mathrm{OR}=2.26)$ when compared with children of the control group, while the frequency of detection of $5 \mathrm{G} / 5 \mathrm{G}+5 \mathrm{G} / 4 \mathrm{G}$ genotypes was significantly increased in the main group $(\mathrm{OR}=2.82)$ (table II).

Further, we analyzed the combinations of polymorphic variants of the studied genes MTHFR C677T and PAI-1
5G/4G. Table III shows statistically significant combinations for the studied genes. We found statistically significant predominance in the control group of children with a combination of genes for the two studied genes $677 \mathrm{CC}$ $+4 \mathrm{G} / 4 \mathrm{G}$ (OR shows a protective effect) comparing to the main group. In the group of children with AIS, the frequency of distribution of the combination of genotypes for the studied genes $677 \mathrm{CT}+5 \mathrm{G} / 5 \mathrm{G}$ was increased, in contrast to the children of the control group, but due to the absence of this combination among the children of the control group, the OR calculation cannot be performed.

The differences revealed in the distribution of individual genotypes and combinations of genotypes indicate that a variant of the MTHFR gene has more pronounced effect in the risk of developing AIS, and its effect is modified by a variant of the PAI-1 gene.

Table III. Significant differences in the frequency distribution of genotypes combinations for the MTHFR C677T and PAI-I 5G/4G genes in the studied groups.

\begin{tabular}{|c|c|c|c|c|c|}
\hline \multirow{3}{*}{$\begin{array}{c}\text { Combination of genotypes of } \\
\text { gene studies }\end{array}$} & \multicolumn{2}{|c|}{ Study group $(n=44)$} & \multicolumn{2}{|c|}{ Control group $(n=33)$} & \multirow[t]{2}{*}{ Significance of differences } \\
\hline & $n$ & $\%$ & $\mathrm{n}$ & $\%$ & \\
\hline & \multicolumn{5}{|c|}{ MTHFR C677T+PAI-1 5G/4G } \\
\hline $677 \mathrm{CC}+4 \mathrm{G} / 4 \mathrm{G}$ & 2 & $4,6 \%$ & 10 & $30,3 \%$ & $\begin{array}{l}x^{2}=7,65, \quad p=0,006, \quad 0 R=0,11 \\
(0,02-0,54)\end{array}$ \\
\hline $677 \mathrm{CT}+5 \mathrm{G} / 5 \mathrm{G}$ & 8 & $18,2 \%$ & 0 & $0,0 \%$ & $x^{2}=4,89, p=0,027$ \\
\hline
\end{tabular}


Due to the possible interaction of the studied polymorphic variants of the MTHFR and PAI-1 genes, the signaling pathways in protein interactions were analyzed.

For this purpose, using the STITCH database, a model of interpreting interactions was built, which allows to predict indirectly the potential intergenic interactions (Figure 2).

Figure 2. Interaction interpretation model.

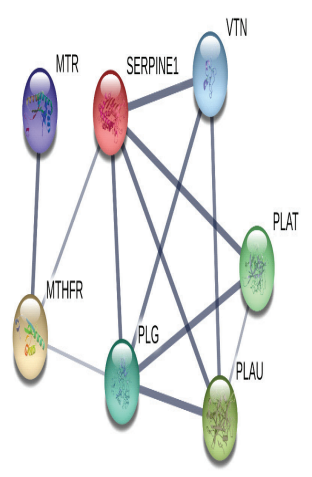

As a result, direct interaction with MTHFR was found for PAI-1, but of weak strength.

\section{DISCUSSION}

A large number of studies on the role of polymorphic variants of the MTHFR C677T gene in the pathogenesis of the development of AIS in childhood has already been published. The most recent was a systematic review and meta-analysis published by Kenet G. et al regarding the effect of thrombophilia on the development of AIS in children; authors revealed an increase in the TT genotype MTHFR gene among children with stroke $(\mathrm{OR}=1.58)$ [10]. Also, in the study based on the meta-analysis involving 822 children with stroke and 1552 children of the control group, Sarecka-Hujar B. et al. emphasized that TT polymorphism of MTHFR gene increases the susceptibility to stroke in children [12].

In our study we could not calculate the OR from the polymorphism TT, since there were no children with this polymorphism among those of the control group. According to our data, the frequency of the $677 \mathrm{~T}$ allele (we calculated association between carriers of the MTHFR T allele: subjects with $\mathrm{CT}+\mathrm{TT}$ genotypes $(\mathrm{CT}+\mathrm{TT}$ : $\mathrm{OR}=3,67)$ ) was significantly higher in children of the study group than of the control group $(\mathrm{OR}=2.57)$. Sarecka-Hujar B. et al. reported the similar observation: a pooled analysis showed that carriers of the $\mathrm{T}$ allele are more common among patients with stroke, compared to people with the CC genotype [12].

In the present study we investigated the association between polymorphism of the PAI-1 gene and AIS in children. In our survey we found that $5 \mathrm{G} / 5 \mathrm{G}+5 \mathrm{G} / 4 \mathrm{G}$ genotypes $(\mathrm{OR}=2.82)$ were more common in the main group, which may indicate that there is no increase in the number of children with pathological mutations 4G/4G among children with stroke.

Different authors described the same results in previous reviews and publications. As a result of analysis of the 70 children with AIS, 140 biological parents and 133 control children, Balcerzyk A. et al concluded that the $4 \mathrm{G} / 5 \mathrm{G}$ polymorphism of the PAI-1gene is not a risk factor for ischemic stroke in Polish children [26].

One of the most recent papers regarding the influence of the PAI-1 gene polymorphisms on the development of stroke in children was published in 2019 by Sarecka-Hujar B. et al. in the form of a systematic review and meta-analysis of the data from a large group (600 children with stroke and 2152 controls); in conclusion they emphasized that PAI-1 gene polymorphisms are not a risk factor for the development of AIS in children [14].

It is possible to assume that polymorphism $4 \mathrm{G} / 4 \mathrm{G}$ leads to the development of a protective effect against the occurrence of AIS in children. Several studies have shown that the $4 \mathrm{G} / 4 \mathrm{G}$ genotype was associated with a decrease in the incidence of stroke. Assawamakin A. et al put forward a detailed hypothesis regarding the reduction in the incidence of stroke in this genotype [24]. The essence of the hypothesis is the combined effect of tissue plasminogen activator ( $t-P A)$, type 1 plasminogen activator inhibitor (PAI-1), and neuroserpine (NSP) on clots, PAI-1 plays a protective role, possibly including the suppression of matrix-degrading enzymes in plaque formation, resulting in limited plaque growth and prevention of abnormal matrix remodeling [24]. The protective role of the $4 \mathrm{G} / 4 \mathrm{G}$ genotype is also indicated in the work of the Sarecka-Hujar B. et al [14] with a link to the publication by Sabino A. et al [27]. Similar to our results, Hoekstra T. et al. described protective value of the $4 \mathrm{G} / 4 \mathrm{G}$ genotype in patients with stroke in older age groups [28]. Endler G.et al postulated in 2000 that the $4 \mathrm{G} / 4 \mathrm{G}$ genotype plays protective pole in young patients with minor stroke [29].

Komitopoulou A. et al, having completed studies of 90 children with AIS and 103 controls, wrote that no definite conclusion could be reached regarding the involvement of the mutations/polymorphisms in genes affecting hemostasis including the PAI-1 gene or the homocysteine metabolism MTHFR C677T in childhood AIS [30]. According to a study by Ozyurek E. et al in 113 Turkish children with cerebral thrombosis (100 of them diagnosed with IS), it was proved that the MTHFR C677T polymorphism may be associated with an increased risk of developing cerebral thrombosis in Turkish children, however, the 4G / 5G genotype of the PAI-1 gene was not found as a significant predictors of CT risk in children [31]. It should also be emphasized that different ethnic populations may have different basic gene polymorphisms, which are more often interpreted as a risk factor for the development of IS in childhood, as many authors indicate in their papers [12, 24].

The association of polymorphic genes variants that can affect the development of AIS in childhood is a subject of numerous investigations. It is reasonable to expect that the presence of combined polymorphisms may have a stronger effect compared to single polymorphisms as published by Herak D. in 2017 [16]. No published data were found on the combination of polymorphic variants only the two genes - MTHFR C677T and PAI-1 5G/4G - on the develop- 
ment of AIS. As our result we showed the direct interaction with MTHFR was found for PAI-1, but of weak strength.

Further studies are needed to analyze the phenotypic manifestations (or clinical effects) of the studied genetic variants for the MTHFR and PAI-1 genes in children with AIS in order to develop therapeutic and prophylactic measures.

We do realize the weak sides of the paper; mainly the number of enrolled AIS patients and the size of control group. We plan to continue our research in the field of stroke risk factors in Ukrainian children population to collect a group on which the research results would be more conclusive. On the other hand- it is the first study presenting Ukrainian children with prothombotic condition predisposing to AIS, so even if we consider the study as a pilot one, we believe it to have a scientific value.

\section{CONCLUSIONS}

We conclude that risk of AIS in children is higher in children with polymorphic variants $677 \mathrm{CT}$ and 677TT for the MTHFR gene and the association of polymorphic variants $5 \mathrm{G} / 4 \mathrm{G}$ and $5 \mathrm{G} / 5 \mathrm{G}$ for the PAI-1 gene with a decrease in the risk of developing AIS. Direct interaction with MTHFR were found for PAI-1, but of weak strength.

\section{REFERENCES:}

[1] deVeber G.:Stroke and the child's brain: an overview of epidemiology, syndromes and risk factors. Current Opinion Neurology 2002; 15: 133-138.

[2] Kirkham F., Hogan A.: Risk Factors for Arterial Ischemic Stroke In Childhood. CNS Spectrums 2004; 9: 451-464.

[3] Mallick A., Ganesan V., Kirkham F., et al.: Childhood arterial ischaemic stroke incidence, presenting features, and risk factors: a prospective population based study. Lancet Neurology 2014; 13: 35-43.

[4] Mackay M., Wiznitzer M., Benedict S., et al.: Arterial ischemic stroke risk factors: the International Pediatric Stroke Study. Annals of Neurology 2011; 69: 130-140.

[5] Steinlin M.: A clinical approach to arterial ischemic childhood stroke: increasing knowledge over the last decade. Neuropediatrics 2012; 43: 1-9.

[6] Gerstl L., Bonfert M., Heinen F., et al.: Childhood Arterial Ischemic Stroke: Clinical Presentation, Risk Factors and Management. Hamostaseologie 2020; 40: 165-173.

[7] Gerstl L., Bonfert M., Nicolai T., et al.: Childhood stroke: What are the special features of childhood stroke? [in German]. Nervenarzt 2017; 88: 1367-1376.

[8] Barnes Ch., deVeber G.: Prothrombotic abnormalities in childhood ischemic stroke. Thrombosis Research 2006; 118: 67-74.

[9] Zadro R.: Inherited prothrombotic risk factors in children with first ischemic stroke. Biochemia Medica 2012; 22: 298-310.

[10] Kenet G., Lutkhoff L., Albisetti M., et al.: Impact of thrombophilia on risk of arterial ischemic stroke or cerebral sinovenous thrombosis in neonates and children: a systematic review and meta-analysis of observational studies. Circulation 2010; 121: 1838-1847.

[11] Haywood S., Liesner R., Pindora S., et al.: Thrombophilia and first arterial ischaemic stroke: a systematic review. Archives of Disease in Childhood 2005; 90: 402-405.

[12] Sarecka-Hujar B., Kopyta, I., Pienczk-Reclawowicz K., et al.: The TT genotype of methylenetetrahydrofolate reductase $677 \mathrm{C}>\mathrm{T}$ polymorphism increases the susceptibility to pediatric ischemic stroke: meta-analysis of the 822 cases and 1,552 controls. Molecular Biology Reports 2012; 39: $7957-7963$.
[13] Sarecka-Hujar B., Kopyta I., Skrzypek M., et al.: Association between the $20210 \mathrm{G}>\mathrm{A}$ prothrombin gene polymorphism an arterial ischemic stroke in children and young adults-two metaanalyses of 3586 cases and 6440 control subjects in total. Pediatric Neurology 2017; 69: 93-10.

[14] Sarecka-Hujar B., Kopyta I., Skrzypek M.: Lack of Associations Between PAI-1 and FXIII Polymorphisms and Arterial IschemicStroke in Children: A Systematic Review and Meta-Analysis. Clinical and Applied Thrombosis Hemostasis 2019; 25: 1-12.

[15] Sharma, P. Meta-analysis of the ACE gene in ischaemic stroke. Journal of Neurology Neurosurgery Psychiatry 1998; 64: 227-230.

[16] Herak C.D., Krleza L.J., Antolic M.R, et al.: Association of polymorphisms in coagulation factor genes and enzymes of homocysteine metabolism with arterial ischemic stroke in children. Clinical and Applied Thrombosis Hemostasis 2017; 23: 1042-1051.

[17] Smulska N., Gorovenko N., Kyriachenko S. et al.: Association of polymorphic variants genes MTHFR (C677T), MTHFR (A1298C), MTRR (A66G), FV (G1691A), FII (G20210A), ACE (I/D) and their combinations with risks of Ischemic Stroke in childhood. [in Ukraine] Ukraine Medical Journal 2014; 3: 131-134.

[18] Smulska N.: Genetic predispose in the development of ischemic stroke in childhood. European Journal of Paediatric Neurology: Thesis of 2d PanSlavic Congress of Child Neurology, Yekaterinburg, Russia. 2014; 18: 822-823.

[19] Smulska N., Gorovenko N., Kyriachenko S.: Genetic aspects of the stroke risk in children. [in Russian ] Emergency Medicine 2015; 1: 8-23.

[20] Li A., Shi Y., Xu L., et al.: A possible synergistic effect of MTHFR C677T polymorphism on homocysteine level variations increased risk for ischemic stroke. Medicine 2017; 96: 51.

[21] Jadavji N.M., Wieske F., Dirnagl U., et al.: Methylenetetrahydrofolate reductase deficiency alters levels of glutamate and gamma-aminobutyric acid in brain tissue. Molecular Genetics and Metabolism Reports 2015; 3: 1-4.

[22] Wiklund P.G., Nilsson L., Ardnor S.N., et al.: Plasminogen activator inhibitor-1 $4 \mathrm{G} / 5 \mathrm{G}$ polymorphism and risk of stroke replicated findings in two nested case-control studies based on independent cohorts. Stroke 2005; 36: 1661-1665.

[23] Yu W., Gwinn M., Clyne M., et al: A navigator for human genome epidemiology. Nature Genetics 2008; 40: 124-125.

[24] Assawamakin A., Sriratanaviriyakul N., Lalerd Y., et al.: Meta-analysis of the plasminogen activator inhibitor-1 (PAl-1) gene with insertion/deletion 4G/5G polymorphism and its susceptibility to ischemic stroke in Thai population. Asian Biomedicine 2012; 6: 203-217.

[25] Golomb M.R., Fullerton H.J., Nowak-Gottl U., et al.: Male predominance in childhood ischemic stroke: finding from the international pediatric stroke study. Stroke 2009; 40: 52-57.

[26] Balcerzyk A., Żak I., Emich-Widera E., et al.:. The plasminogen activator inhibitor-1 gene polymorphism in determining the risk of pediatric ischemic stroke--case control and family-based study. Neuropediatrics 2011; 42: 67-70.

[27] Sabino A. P., Ribeiro D.D., Domingueti C.P., et al.: Plasminogen activator inhibitor - $14 \mathrm{G} / 5 \mathrm{G}$ promoter polymorphism and PAl-1 plasma levels in young patients with ischemic stroke. Molecular Biology Reports 2011; 38: $5355-5360$.

[28] Hoekstra T., Geleijnse J.M., Kluft C., et al.: 4G/4G genotype of PAl-1 gene is associated with reduced risk of stroke in elderly. Stroke 2003; 34: 2822-2828.

[29] Endler G., Lalouschek W., Exner M., et al.: The 4G/4G genotype at nucleotide position -675 in the promotor region of the plasminogen activator inhibitor 1(PAl-1) gene is less frequent in young patients with minor stroke than in controls. British Journal of Haematology 2000; 110 : 469-471.

[30] Komitopoulou A., Platokouki H., Kapsimali Z., et al.: Mutations and polymorphisms in genes affecting hemostasis proteins and homocysteine metabolism in children with arterial ischemic stroke. Cerebrovascular Diseases 2006; 22: 13-20.

[31] Ozyurek E., Balta G., Degerliyurt A., et al.: Significance of factor V, prothrombin, MTHFR, and PAI-1 genotypes in childhood cerebral thrombosis. Clinical and Applied Thrombosis Hemostasis 2007; 13: 154-160. 